\title{
ANALISIS KEBUTUHAN TENAGA KERJA BERDASARKAN BEBAN KERJA DENGAN METODE WORKLOAD INDICATOR OF STAFFING NEED (WISN) DI UNIT REKAM MEDIS RUMAH SAKIT RAFFLESIA BENGKUL
}

\author{
Nofri Heltiani \\ Akademi Kesehatan Sapta Bakti Bengkulu
}

\begin{abstract}
ABSTRAK
Beban kerja merupakan salah satu komponen penting dalam menghitung kebutuhan tenaga. Artinya jumlah tenaga yang dibutuhkan disesuaikan dengan beban kerja yang ada. Metode Workload Indicator of Staffing Need (WISN) adalah metode untuk menghitung kebutuhan tenaga kerja berdasarkan beban kerja nyata yang dilaksanakan oleh tenaga kerja. Penelitian ini bertujuan untuk mengetahui kebutuhan tenaga dengan metode WISN. Penelitian ini dilaksanakan di Unit Rekam Medis Rs Rafflesia Bengkulu selama 6 hari. Penelitian ini menggunakn pendekatan kualitatif dengan melakukan observasi, wawancara mendalam dan telaah dokumen. Hasil penelitian didapatkan penggunaan waktu kerja staff adalah 2200 jam/tahun. Hasil perhitungan tenaga dengan metode WISN didapatkan jumlah tenaga Unit Rekam Medis RS Rafflesia Bengkulu adalah 6 orang. Dari hasil penelitian ini dsarankan kepada Manajemen RS Rafflesia Bengkulu perlu adanya pertimbangan menambah tenaga staff dengan lulusan DIII Rekam Medis di Unit Rekam Medis RS Rafflesia Bengkulu sebanyak 4 orang.
\end{abstract}

\section{PENDAHULUAN}

Menurut Keputusan Menteri Pendayagunaan Aparatur Negara Nomor 30/KEP/M.PAN/12/2013 tentang Jabatan Fungsional Perekam Medis dan Angka Kreditnya, untuk formasi jabatan fungsional Perekam Medis di Rumah Sakit Umum bertipe A harus berjumlah 70 orang dengan kualifikasi terampil dan 20 orang dengan kualifikasi ahli. Untuk Rumah Sakit Umum bertipe B harus berjumlah 45 orang dengan kualifikasi terampil dan 10 orang dengan kualifikasi ahli. Untuk Rumah Sakit Umum bertipe $\mathrm{C}$ harus berjumlah 30 orang dengan kualifikasi terampil dan 6 orang dengan kualifikasi ahli, sedangkan untuk Rumah Sakit Umum bertipe D harus berjumlah 15 orang dengan kualifikasi terampil dan 4 orang dengan kualifikasi ahli. Dalam Peraturan Menteri Kesehatan RI Nomor. 741/MENKES/Per/VII/2008 tentang Petunjuk Teknis Standar Pelayanan Minimal, menjelaskan standar pelayanan bagi unit rekam medis dalam menjalankan tugasnya. Seperti pendaftaran pasien diselesaikan dalam waktu 120 detik, pengentrian data pasien diselesaikan dalam waktu 60 detik, pencarian bekas rekam medis pasien diselesaikan dalam waktu 5 detik, pendistribusian berkas rekam medis pasien diselesaikan dalam waktu 60 detik, assembling diselesaikan dalam waktu 45 detik, coding diselesaikan dalam waktu 60 detik, indeks diselesaikan dalam waktu 30 detik, sortir berkas rekam medis pasien diselesaikan dalam waktu 5 detik dan filing diselesaikan dalam waktu 90 detik. Rumah Sakit Rafflesia Bengkulu adalah rumah sakit bertipe $D$, dengan kapasitas tempat tidur 86 buah, yang didirikan pada tanggal 18 November 1981 sebagai Klinik Rafflesia. Yang berlokasi di kawasan Jalan Mahoni Nomor 10 Kota Bengkulu. Sebagai rumah sakit swasta, Rumah Sakit Rafflesia Bengkulu menyelenggarakan sebuah Balai Kesehatan Masyarakat (Balkesmas) yang mencangkup pelayanan usaha pokok serta bertanggung jawab juga dalam perbaikan tingkat kesehatan masyarakat di Provinsi Bengkulu. Rumah Sakit Rafflesia melayani pasien asuransi dan umum, dengan jumlah pasien perharinya dapat mencapai 100150 pasien per-harinya. Sedangkan pada tahun 2014 jumlah pasien sebanyak 28.564 pasien, tahun 2015 jumlah pasien sebanyak 33.711 dan tahun 2016 jumlah pasien sebanyak 39.509 pasien. Dengan jumlah lulusan DIII Rekam Medis sebanyak 2 orang. Selain itu Rumah Sakit Rafflesia Bengkulu, untuk perencanaan kebutuhan tenaga kesehatan khususnya di unit rekam medis belum ada, sehingga kebijakan 
dalam perencanaan kebutuhan tenaga di unit rekam medis belum jelas. Dilihat dari segi alur proses kebijakan perencanaan kebutuhan tenaga rekam medis, langkah-langkah, koordinasi dan proses konsultasi terkait perencanaan SDM belum terstruktur dengan baik. Selama ini perencanaan kebutuhan tenaga kerja di unit rekam medis masih ersifat administratif kepegawaian dan belum dikelola secara profesional. Akibatnya tenaga yang ada belum sesuai denga kompetensi dan kebutuhan nyata di lapangan. Untuk mencukupi kebutuhan akan tenaga rekam medis, Rumah Sakit Rafflesia menggunakan jasa tenaga teknis pada unit rekam medis dengan melalui proses administrasi tanpa melalui proses perhitungan kebutuhan tenaga kesehatan berdasarkan Kepmenpan atau pun WISN. Selain tidak memilikinya sistem perencanaan kebutuhan tenaga kerja, Rumah Sakit Rafflesia pun belum memiliki Standar Operasional Prosedur atau SOP. Maka dari itu penulis tertarik untuk menelti tentang "Analisis Kebutuhan Tenaga Kerja Dengan Metode Workload Indicator Of Staffing Need (WISN) di Unit Rekam Medis Rumah Sakit Rafflesia Bengkulu Tahun 2016". Peneliti ini bertujuan

\section{HASIL PENELITIAN}

\section{Menetapkan Waktu Kerja Tersedia}

Tabel 1 Waktu Kerja Tersedia di Unit Rekam Medis RS Rafflesia Bengkulu Tahun 2016

\begin{tabular}{|c|l|c|c|}
\hline Kode & \multicolumn{1}{|c|}{ Item } & Jumlah & Keterangan \\
\hline A & Hari Kerja & 365 & Hari/Tahun \\
\hline B & Cuti Tahunan & 12 & Hari/Tahun \\
\hline C & Pendidikan dan Pelatihan & 1 & Hari/Tahun \\
\hline D & Hari Libur & 72 & Hari/Tahun \\
\hline E & Ketidakhadiran Kerja & 5 & Hari/Tahun \\
\hline F & Waktu Kerja & 8 & Hari/Tahun \\
\hline & Hari Kerja Tersedia & $\mathbf{2 7 5}$ & Hari/Tahun \\
\hline$\quad$ Waktu Kerja Tersedia & $\mathbf{2 2 6 4}$ & Jam/Tahun \\
\hline
\end{tabular}

Untuk perhitungan sebagai berikut :

1. Untuk hari kerja tersedia

Seluruh Kategori SDM $:\{365-(12+1+72+5)\}=275$ Hari Kerja/Tahun

2. Waktu Kerja Tersedia

Seluruh Kategori SDM :275 (Hari/Tahun) x 8 Jam/Hari =2.200 Jam Kerja/Tahun

Berdasarkan rumus tersebut, maka didapatkan waktu kerja yang disediakan bagi staff Unit Rekam Medis Rumah Sakit Rafflesia Bengkulu dihitung dari hari kerja selama satu tahun (288 hari), dikurangi hari cuti tahunan (12 hari) dan ketidakhadiran kerja (3 hari) dalam waktu satu tahun dan dkalikan lama waktu kerja sehari di unit rekam medis, hasilnya adalah sebesar 2.200/orang/jam/tahun dan $\mathbf{2 7 5}$ hari kerja efektif selama satu tahun. 


\section{Menyusun Standar Beban Kerja}

Tabel 2 Standar Beban Kerja di Unit Rekam Medis

RS Rafflesia Bengkulu Tahun 2016

\begin{tabular}{|c|c|c|c|}
\hline NO & & Uraian Kegiatan & $\begin{array}{l}\text { Waktu Per } \\
\text { Menit }\end{array}$ \\
\hline \multirow{6}{*}{1} & \multirow{6}{*}{ Kegiatan Pokok } & 1. Pencatatan status masuk & 0,5 \\
\hline & & 2. Assembling & 0,75 \\
\hline & & 3. Coding & 1 \\
\hline & & 4. Indeksing & 0,5 \\
\hline & & 5. Filling & 1,5 \\
\hline & & 6. Pengecekan Posisi Keberadaan Status & 3,25 \\
\hline \multirow{2}{*}{\multicolumn{3}{|c|}{$\begin{array}{c}\text { Total Per Menit } \\
\text { Standar Beban Kerja Kegiatan Pokok }\end{array}$}} & 7,5 \\
\hline & & & 17.600 \\
\hline \multirow{11}{*}{2} & \multirow{11}{*}{$\begin{array}{l}\text { Kegiatan } \\
\text { Tambahan }\end{array}$} & 1. Menyerahkan format data sosial/KIUP & 0,083 \\
\hline & & 2. Menunggu hasil isian format data & 2 \\
\hline & & 3. Membuat kartu berobat & 0,5 \\
\hline & & $\begin{array}{l}\text { 4. Menyiapkan BRM baru bagi pasien } \\
\text { baru }\end{array}$ & 1 \\
\hline & & 5. Mengisi buku registrasi & 0,5 \\
\hline & & 6. Mencari BRM di rak penyimpanan & 0,25 \\
\hline & & $\begin{array}{l}\text { 7. Membuat SEP dan SJP bagi pasien } \\
\text { BPJS }\end{array}$ & 1 \\
\hline & & 8.Pendistribusian BRM & 0,75 \\
\hline & & 9. Mengentri data pasien & 0,5 \\
\hline & & $\begin{array}{l}\text { 10. Pengambilan BRM dari ruang } \\
\text { perawatan }\end{array}$ & 5 \\
\hline & & 11. Mensortir BRM & 0,083 \\
\hline \multicolumn{3}{|r|}{ Total Per Menit } & 12 \\
\hline \multicolumn{3}{|c|}{ Standar Beban Kerja Kegiatan Tambahan } & 11.000 \\
\hline \multicolumn{3}{|c|}{ Total Keseluruhan Standar Beban Kerja } & 28.600 \\
\hline
\end{tabular}

Perhitungan sebagai berikut : Diketahui : a. Waktu Kerja Tersedia $=$ 132000 Menit/Tahu $\mathrm{n}$

b. Rata-Rata Waktu Kegiatan Pokok $=7,5$ Menit

Rata-Rata Waktu Kegiatan Tambahan = 12 Menit

Ditanya : Standar Beban Kerja ?

Jawab :Standar Beban Kerja

Kegiatan Pokok

$=\frac{\text { Waktu Kerja Tersedia }}{\text { Rata-Rata Waktu Kegiatan }}$

$=\frac{132000}{7,5}$

$=\quad 17.600$

Kegiatan Tambahan

$=\frac{\text { Waktu Kerja Tersedia }}{\text { Rata-Rata Waktu Kegian }}$

Rata-Rata Waktu Kegiatan

$=132000$

$=\quad 11.000$

Total Standar Beban Kerja Keseluruhan = Standar beban kerja kegiatan pokok + standar beban kerja kegiatan tambahan

$=17.600+11.000$

$=28.600 \mathrm{Menit} /$ Tahun 


\section{Menyusun Standar Kelonggaran}

Tabel 3 Waktu Kelonggaran di Unit Rekam Medis RS Rafflesia Bengkulu Tahun 2016

\begin{tabular}{|c|c|c|c|c|}
\hline No & Faktor Kelonggaran & $\begin{array}{c}\text { Rata-Rata } \\
\text { Waktu }\end{array}$ & Jumlah & $\begin{array}{c}\text { Standar } \\
\text { Kelonggaran }\end{array}$ \\
\hline 1 & Rapat Rutin & 2 Jam/Bulan & 24 Jam/Tahun & 0,0109 \\
\hline 2 & Seminar & 1 Hari & 5 Jam & 0,0022 \\
\hline \multicolumn{4}{|c|}{ Total Standar Waktu Kelonggaran } \\
\hline
\end{tabular}

Untuk perhitungannya sebagai berikut :

Diketahui : Rata-rata $=1440$ Menit/Tahun (Rapat Rutin)

Rata-rata $=300$ Menit/Tahun (Seminar)

Waktu Kerja Tersedia $=132000$ Menit/Tahun

Ditanya

Jawab

Total Keseluruhan

: Standar Kelonggaran?

: Standar Kelonggaran $=\underline{\text { Rata Rata Waktu Rapat Rutin }}$ Waktu Kerja Tersedia

$$
=
$$$$
1440
$$$$
132000
$$

$=0,0109 \mathrm{Menit} /$ Tahun

Standar Kelonggaran $=$ Rata Rata Waktu Seminar

$$
\text { Waktu Kerja Tersedia }
$$

$$
=\frac{300}{132000}
$$

$$
=0,0022 \text { Menit/Tahun }
$$

$$
\begin{aligned}
& =0,0109+0,0022 \\
& =\mathbf{0 , 0 1 3 1} \text { Menit } / \text { Tahun }
\end{aligned}
$$

Berdasarkan hasil perhitungan diketahui bahwa waktu standar kelonggaran berdasarkan rata-rata waktu per faktor kelongaran didapatkan proporsi faktor kelonggaran ialah 0,0131 Menit/Tahun

\begin{tabular}{|c|c|c|c|c|c|}
\hline NO & $\begin{array}{l}\text { Kategori } \\
\text { Kegiatan }\end{array}$ & $\begin{array}{c}\text { Kuantitas } \\
\text { Kegiatan } \\
\text { Pokok }\end{array}$ & $\begin{array}{c}\text { Standar } \\
\text { Beban } \\
\text { Kerja }\end{array}$ & $\begin{array}{c}\text { Standar } \\
\text { Kelonggaran }\end{array}$ & $\begin{array}{c}\text { Kebutuhan } \\
\text { SDM }\end{array}$ \\
\hline 1 & Kegiatan Pokok & \multirow[b]{2}{*}{39.509} & 17.600 & \multirow[b]{2}{*}{0,0131} & 2 \\
\hline 2 & $\begin{array}{l}\text { Kegiatan } \\
\text { Tambahan }\end{array}$ & & 11.000 & & 4 \\
\hline
\end{tabular}

4. Menetapkan Kuantitas Kegiatan Pokok

Tabel 4 Total Kunjungan Pasien RS Rafflesia Bengkulu Tahun 2016

\begin{tabular}{|c|c|}
\hline Kegiatan Pokok & Frekuensi (Pasien) \\
\hline Pasien Baru & 17.485 \\
\hline Pasien Lama & 21.664 \\
\hline Total & $\mathbf{3 9 . 5 0 9}$ \\
\hline
\end{tabular}

5. Kebutuhan Tenaga Kerja di Unit Rekam Medis Rumah Sakit Rafflesia Bengkulu Tabel 5 Kebutuhan Tenaga Kerja di Unit Rekam Medis

RS Rafflesia Bengkulu Tahun 2016

Perhitungan sebagai berikut :

Kebutuhan SDM berdasrakan kegiatan pokok dan tambahan

Sub Total Kebutuhan SDM = Kuantitas Kegiatan Pokok

Standar Beban Kerja

$$
\begin{aligned}
& =\frac{39509}{17600}+0,0131 \\
& =2,2448+0,0131
\end{aligned}
$$




$\begin{aligned} & =2,2579 \\ & =\mathbf{2} \\ \text { Sub Total Kebutuhan SDM } & =\frac{\text { Kuantitas Kegiatan Tambahan }}{\text { Standar Beban Kerja }} \\ & =\frac{39509}{11000}+0,0131 \\ & =3,5917+0,0131 \\ & =3,9648 \\ & =\mathbf{4} \quad \mathbf{6} \text { orang }\end{aligned}$

Dari tabel 5 di atas, diketahui hasil perhitungan kebutuhan tenaga kerja berdasarkan metode WISN adalah 6 orang. Untuk jumlah tenaga saat ini di Unit Rekam Medis Rumah Sakit Rafflesia Bengkulu adalah 2 orang dengan basic lulusan DIII Rekam Medis, sehingga dibutuhkan penambahan staff sebanyak 4 orang dengan basic lulusan DIII Rekam Medis.

\section{PEMBAHASAN}

\section{Menetapkan Waktu Kerja Tersedia}

Waktu kerja tersedia di unit rekam medis RS Rafflesia Bengkulu dalam satu tahun adalah 275 hari kerja atau 2200 jam/tahun. Variabel perhitungan waktu kerja tersedia didapatkan dari total jumah hari dalam satun tahun dikurangi jumlah hari libur berdasarkan jadwal shift yang dibuat, cuti tahunan, pendidikan dan pelatihan dan ketidkhadiran kerja dalam satu tahun. Adapun waktu kerja efektif didapatkan dari rata-rata shift dalam satu hari yaitu 8 jam. Berdasarkan hasil penelitian pada tabel 1, didapatkan waktu kerja tersedia di Unit Rekam Medis Rumah Sakit Rafflesia masih rendah yaitu hanya sebesar 2200 jam/tahun dibandingkan hasil standar yaitu 18.120 jam/tahun, ini dipengaruhi oleh waktu libur yang tidak sesuai standar dimana dalam satu tahunnya sebanyak 72 hari/tahun (libur berdasarkan shift/kebijakan pada Rumah Sakit Rafflesia Bengkulu). Sedangkan menurut Undang-Undang Republik Indonesia Nomor 13 Tahun 2003 Tentang Ketenagakerjaan Pasal 79 Ayat 2b bahwa istirahat mingguan 1 (satu) hari untuk 6 (enam) hari kerja dalam 1 (satu) minggu atau 2 (dua) hari untuk 5 (lima) hari kerja dalam 1 (satu) minggu, sedangkan di Unit Rekam Medis Rumah Sakit Rafflesia Bengkulu mendapatkan libur selama 2 hari setelah selesai menjalankan shift malam dengan hari kerja selama 6 hari kerja, diitambah lagi staff yang mengambil waktu cuti tahunan lebih dari 12 hari. Ini menyebabkan aktifitas produktif (pengecekan status, pengkodingan berkas rekam medis, pembuatan indeks penyakit dan tindakan dan sebagainya) di unit rekam medis kurang terlaksana dengan baik selain aktifitas produktif kurang terlaksana juga menyebabkan kegiatan-kegiatan yang lainnya menumpuk, seperti berkas yang sudah dikembalikan tidak dapat disusun ke rak penyimpanan, tidak rapinya rak penyimpanan ditambah lagi dengaan kurang tertibnya pasien dalam mengantri untuk mendaftar serta kurang sabarnya pasien dalam menunggu proses pelayanan hal ini mengakibatkan staff harus memberikan penjelasan dan ini akan memakan waktu kerja serta membuat waktu kerja tersedia menjadi tidak efektif.

\section{Menyusun Standar Beban Kerja}

Berdasarkan tabel 2, berdasarkan aktifitas pengamatan di Unit Rekam Medis Rumah Sakit Rafflesia Bengkulu diperoleh data bahwa proporsi beban kerja pada unit rekam medis sebesar 29.432 menit/tahun, sedangkan hasil standar yang ada sebesar 31.980 menit/tahun. Ini disebakan pada Unit Rekam Medis Rumah Sakit Rafflesia Bengkulu masih belum memiliki standar alokasi waktu dalam mengerjakan kegiatan yang ada, Standar Operasional Prosedur (SOP) dalam mengerjakan kegiatan yang ada serta kurang jelasnya job description bagi setiap staff. Kegiatan-kegiatan pokok misalnya 
pengkodingan berkas rekam medis, pembuatan indeks penyakit, pengecekan posisi status, assembling masih dilimpahkan semuanya kepada staff dengan basic DIII Rekam Medis, sedangkan staff dengan lulusan DIII Rekam Medis hanya terdiri 2 orang saja serta staff tersebut harus juga mengerjakan kegiatan tambahan lainnya seperti pengambilan berkas rekam medis dari ruang rawat inap, pengentrian status pasien dan sebagainya. Selain itu pada Unit Rekam Medis Rumah Sakit Rafflesia Bengkulu pengerjaan kegiatan pokok dilakukan setelah kegiatan tambahan telah selesai dilakukan atau disela-sela kegiatan tambahan dikarenakan fokus utama penyelesaian kegiatan per harinya adalah kegiatan pendaftaran pasien yang akan berobat (kegiatan ini termasuk dalam kegiatan tambahan), serta banyaknya pasien yang mendaftar, kurang sabarnya pasien dalam mengantri dan berkas yang sulit untuk ditemukan dan membuat beban kerja di unit rekam medis cukup tinggi.

\section{Kebutuhan Tenaga Kerja di Unit Rekam}

Medis Rumah Sakit Rafflesia Bengkulu

Perhitungan kebutuhan tenaga kerja di Unit Rekam Medis Rumah Sakit Rafflesia Bengkulu dihitung berdasarkan metode WISN menghasilkan perhitungan jumlah kebutuhan tenaga kerja sebanyak 6 orang. Dengan kondisi saat ini di Unit Rekam Medis Rumah Sakit Raffesia memiliki 2 orang tenaga yang lulusan DIII Rekam Medis, walaupun saat ini

\section{SIMPULAN}

1. Jumlah waktu kerja yang tersedia di Unit Rekam Medis Rumah Sakit Rafflesia Bengkulu tahun 2016 dalam 1 tahun adalah 275 hari atau 2200 jam/tahun.

2. Standar besar beban kerja staff Unit Rekam Medis Rumah Sakit Rafflesia Bengkulu tahun 2016 dihitung berdasarkan kegiatan yang dilaksanakan oleh staff yang ada yaitu 28.600 menit/tahun.

\section{DAFTAR PUSTAKA}

\section{Menyusun Standar Kelonggaran}

Dari tabel 3 diatas, diketahui bahwa standar kelonggaran yang diperoleh sebesar 0.0131 menit/tahun, sedangkan pada hasil standar didapatkan hasil 0,192 menit/tahun. Standar kelonggaran di Unit Rekam Medis Rumah Sakit Rafflesia dapat dikatakan masih cukup rendah, hal ini disebakan karena masih kurangnya kegiatan-kegiatan yang dapat mendukung serta bermanfaat bagi staff di unit rekam medis seperti pelatihan dan pendidikan bagi staff rekam medis, rapat profesi perekam medis dan juga selain disebabkan oleh hal tersebut juga dikarenakan jumlah pasien per hari yang datang untuk beobat cukup banyak mencapai 100-150 pasien per harinya, sehingga waktu untuk kegiatan lainnya yang bermanfaat dan mendukung bagi staff unit rekam medis masih belum dilaksanakan dengan baik serta salah satu faktornya juga karena jumlah fasilitas untuk penyelenggaraan kegiatan tersebut belum memadai.

Unit Rekam Medis Rumah Sakit Rafflesia memiliki 10 orang staff di unit rekam medis tetapi masih banyak kegiatan yang kurang dilaksanakan dengan baik atau kegiatan yang masih dilimpahkan semua untuk dikerjakan oleh lulusan DIII Rekam Medis saja, seperti kegiatan pokok masih semua harus dikerjakan oleh lulusan DIII Rekam Medis. Sehingga dibutuhkan penambahan tenaga kerja dengan lulusan DIII Rekam Medis sebanyak 4 orang lagi.

3. Standar kelongaran staff Unit Rekam Medis Rumah Sakit Rafflesia Bengkulu tahun 2016 sebesar 0,0131 menit/tahun.

4. Jumlah kuantitas kegiatan pokok Unit Rekam Medis Rumah Sakit Rafflesia Bengkulu tahun 2016 sebanyak 39.509 pasien.

5. Berdasarkan perhitungan kebutuhan tenaga kerja dengan menggunakan metode WISN (Workload Indicator Staffing Need) di Unit Rekam Medis Rumah Sakit Rafflesia Bengkulu tahun 2016 didapatkan hasil sebesar 6 orang.

Andrew, R. 1997. Manajemen Sumber Daya Manusia, Human Resoure Management. 
Jilid I Edisi Bahasa Indonesia. Jakarta: Indeks.

Arikunto, S. 2006. Manajemen Penelitian. Rineka Cipta, Jakarta.

Barnes, M. 1980. Motion and Time Study and Measurenment of Work Seventh Edition California. California.

Departemen Kesehatan RI. 2006. Pedoman Pengelolahan Rekam Medis Rumah Sakit di Indonesia Revisi II. Jakarta: Dirjen Yanmed.

Edna, H. 1981. Health Information Management. Berwyn, Illiniois : Physicians Record Company.

Gunadi, S. 1997. Studi Tentang Beban Kerja Perawat di Unit Rawat Inap Penyakit Dalam Rumah Sakit Tebet, Tesis Fakultas Kesehatan Masyarakat, Universitas Indonesia Depok.

Ilyas, Y. 2013. Perencanaan SDM Rumah Sakit : Teori, Metoda dan Formula Fakultas Kesehatan Masyarakat, Universitas Indonesia, Depok.

Indriana, N. 2009. Analisis Kebutuhan Personil di Bagian Human Resource Departement Rumah Sakit Karya Bakti Bogor. Skripsi $\mathrm{S}$ Fakultas Kesehatan Masyarakat, Universitas Indonesia, Depok.

Hasibuan, P. 2001. Manajemen Sumber Daya Manusia. Jakarta: PT. Binarupa Bumi Aksara.

Kementerian Kesehatan Republik Indonesia. 2004. Keputusan Menteri Kesehatan Republik Indonesia Nomor 81/Menkes/SK/I/2004 Tentang Pedoman Penyusunan Perencanaan Sumber Daya Manusia Kesehatan di Tingkat Provinsi, Kabupaten/Kota serta Rumah Sakit. Jakarta: Kemenkes RI.
Kementerian Kesehatan Republik Indonesia. 2008. Keputusan Menteri Kesehatan Republik Indonesia Nomor. 129/Menkes/Per/VII/2008 Tentang Standar Pelayanan Minimal Rumah Sakit. Jakarta : Kemenkes RI.

Kementerian Pendayagunaan Aparatur Negara Republik Indonesia. 2013. Keputusan Menteri Pendayagunaan Aparatur Negara Nomor 30/KEP/Menpan/12/2013 Tentang Jabatan Fungsional Perekam Medis dan Angka Kreditnya, untuk formasi jabatan fungsional Perekam Medis di Rumah Sakit Umum Berdasarkan Tipe Rumah Sakit. Jakarta : Kemenpan RI.

Mangkunegara, P \& Anwar. 2008. Perencanaan dan Pengembangan Sumber Daya Manusia Perusahaan. Bandung: PT Retika Aditama.

Mangkuprawira, S. 2003. Manajemen Sumber Daya Manusia Strategik. Jakarta: Ghalia Indonesia.

Muthomimah, I \& Maryani S, 2015. Analisis Kebutuhan Tenaga Kerja Berdasarkan Beban Kerja Unit Rekam Medis Rumah Sakit Islam Kendal. Jawa Tengah, Jurnal Tidak Dipublikasikan.

Notoatmodjo, S. 2003. Metodologi Penelitian Kesehatan. Rineka Cipta, Jakarta.

Nursalam. 2003. Konsep \& Penerapan Metodelogi Penelitian Ilmu Keperawatan : Pedoman Skripsi, Tesis dan Instrumen Penelitian. Salemba Medika, Jakarta.

Patuwo, B. 2005. Analisis Kebutuhan Tenaga Analisis di Unit Laboratorium Pelayanan Kesehatan St. Carolus Tahun 2005. Tesis Program Pascasarjana Fakultas Kesehatan Masyarakat, Universitas Indonesia, Depok.

Penelitian dari An Australian Gaduate School of Management. 2009. Tentang Penelitian 
Kerja dan Pengukuran Kerja Seri pada Organisasi, Australia.

Rivai, V. 2008. Manajemen Sumber Daya Manusia Untuk Perusahaan Dari Teori Ke Praktik. Jakarta : PT. Rajagrafindo Persada.

Seno, Bayu RW. 2015. Analisis Kebutuhan Tenaga Kerja Berdasarkan Beban Kerja Di Loket Pendaftaran BPJS Rumah Sakit Haji Jakarta. Skripsi, S-1 Program Strata 1 Studi Kesehatan Masyarakat.

Sudra, I. 2009. Pedoman Penyelenggaraan Rekam Medis, Depok : Graha Ilmu.
Sugiyono, DR. 2007. Statistika Untuk Penelitian. Alfabet, Bandung.

Soeroso, S. 2003. Manajemen Sumber Daya Manusia di Rumah Sakit-Suatu Pendekatan Sistem. Jakarta: Buku Kedokteran EGC.

Sofyandi, H. 2008. Manajemen Sumber Daya Manusia. Yogyakarta: Graha Ilmu.

Yunita P, 2015. Analisis Kebutuhan Tenaga Kerja Berdasarkan Beban Kerja Nyata Dengan Metode WISN di Instalasi Farmasi Rumah Sakit Tugu Ibu. Depok, Jurnal Tidak Dipublikasikan. 